\title{
ANALISIS PERATAAN LABA PADA PERUSAHAAN INDUSTRI MAKANAN DAN MINUMAN
}

\author{
Febi Fatimah \\ R. Deni Muhammad Danial \\ Faizal Mulia Z \\ Fakultas Ilmu Administrasi dan Humaniora, \\ Universitas Muhammadiyah Sukabumi \\ fatimahfebifatimah@gmail.com ${ }^{*}$
}

\begin{abstract}
The purpose of this study was to analyze the practice of income smoothing in food and beverage industry companies. Income smoothing is the intentional reduction of earnings fluctuations in an effort to stabilize profits to be considered normal for a company. This data is obtained from www.idx.co.id. The population in this study were food and beverage companies listed on the Indonesia Stock Exchange for the period of 2014-2016. The sampling technique used was using the purposive sampling method from 16 samples to 10 samples used. The data analysis technique of this research is descriptive statistical analysis techniques. To calculate income smoothing using the Eckel Index formula. The results of this study indicate that 6 companies carry out income smoothing practices and 4 companies do not.
\end{abstract}

Keywords: Income Smoothing, Index Eckel

\section{PENDAHULUAN}

Perusahaan industri makanan dan minuman atau yang disingkat dengan perusahaan mamin ini memiliki peluang untuk terus tumbuh dan berkembang khususnya di negara Indonesia. Peluang tersebut dapat dilihat dari seiring semakin meningkatnya pertumbuhan jumlah penduduk di indonesia maka, semakin meningkat pula kebutuhan masyarakat indonesia terhadap konsumsi makanan dan minuman. Ditambah lagi dengan pertumbuhan industri mamin seiring waktu terus mengalami peningkatan yang pada tahun 2015 mencapai $7,54 \%$, lalu ditahun 2016 mencapai 8,46\% dan di tahun 2017 mencapai 9,23\%.

Menguatnya kondisi ini menarik minat para investor untuk berinvestasi. Kondisi ini membuat persaingan semakin ketat sehingga para manajemen perusahaan harus berlomba lomba menarik investor untuk menginvestasikan dananya di perusahaannya. Salah satu cara dalam menarik investor itu dari kinerja laporan keuangan. Karena laporan keuangan merupakan sebuah informasi yang sangat penting dijadikan untuk membuat suatu keputusan ataupun perencanaan bagi para investor.

Akhir akhir ini banyak sekali dijumpai kecenderungan para investor yang lebih melirik ukuran laba suatu perusahaan dalam menentukan investasinya. Hal tersebut dikarenakan laba ini dapat memberikan informasi mengenai penaksiran risiko dalam berinvestasi. Namun kebanyakan investor yang memusatkan perhatiannya pada informasi laba ini tidak memperhatikan prosedur-prosedur didalamnya. Dimana para investor harusnya berhati hati dalam 
meminjamkan dananya pada perusahaan, apakah perusahaan yang diinvestasikannya dapat menjamin penghasilan yang tetap atau tidak. Karena tujuan berinvestasi adalah mendapatkan penghasilan yang tetap. Oleh karena itu para investor biasanya sebelum melakukan investasi ia akan melihat kemampuan perusahaan tersebut bagaimana dalam menghasilkan laba, semakin baik suatu perusahaan menghasilkan laba maka semakin tertarik pula para investor untuk berinvestasi.

Ditemukan beberapa masalah yang tidak sedikit perusahaan perusahaan mengalami kegagalan karena laba yang dihasilkan semakin menurun, ada juga yang mengalami kondisi laba yang tidak stabil akibat dampak dari krisis ekonomi global. Keadaan kondisi laba yang tidak stabil ini menjadikan sebuah ancaman bagi investor yang sudah berinvestasi pada perusahaan tersebut maupun yang belum melakukan. Manajemen harus melakukan segala upaya agar laba yang dihasilkan suatu perusahaannya dapat membuat para investor untuk berinvestasi bahkan menaikkan investasinya.

Laba yang dihasilkan oleh suatu perusahaan semakin meningkat memang dikatakan baik, namun bagi investor laba yang semakin meningkat itu perlu dipertimbangkan kembali. Para investor lebih memilih laba yang rata dari tahun ke tahun dibandingkan yang terus meningkat, karena ditakutkan akan terjadinya fluktuasi yang berlebihan. Laba yang rata dari tahun ke tahun mengindikasikan bahwa suatu perusahaan tersebut kuat dan stabil. Laba yang relatif stabil pada umumnya disukai oleh para investor. Dengan fakta tersebut para manajemen merasa tertarik untuk melakukan perilaku tak semestinya (disfunctional behaviour) yakni dengan perataan laba. Perilaku tak semestinya ini juga dilakukan karena adanya suatu peluang dari asimetri informasi. Asimetri informasi ini ialah terjadinya ketidakseimbangan informasi yang didapatkan antara pihak eksternal yakni investor dengan pihak internal yakni manajemen keuangan itu sendiri. Pihak internal lebih mengetahui secara rinci apa yang terjadi dalam perusahaan dan lebih cepat dalam menerima informasi internal perusahaan sementara, pihak eksternal ia berada diposisi yang tidak pasti dalam mengetahui secara rinci kondisi perusahaan. Dengan kondisi tersebut, ini dijadikan sebuah kesempatan manajemen dalam menggunakan informasi yang diketahuinya untuk memanipulasi pelaporan keuangan.

Perataan laba adalah memindahkan pendapatan dari tahun tahun yang tinggi ke periode tahun yang kurang menguntungkan untuk mengurangi fluktuasi laba. Perataan laba ini juga bertujuan agar mudah dalam menarik para investor dan manajemen dapat merauk keuntungan sebesar besarnya tanpa melihat akibat atau dampak yang terjadi sesudahnya. Perataan laba juga mampu memperbaiki sebuah citra perusahaan dan meningkatkan relasi-relasi usaha. Namun perataan laba ini tidak baik dilakukan karena, tidak menggambarkan kondisi keuangan sesungguhnya dan bertentangan terhadap tujuan suatu perusahaan. Juga perataan laba memberikan informasi laporan keuangan yang menyesatkan bagi si pengguna laporan keuangan, sehingga dapat mengakibatkan pengguna laporan keuangan salah dalam mengambil keputusan. Dan jika perataan laba ini sampai diketahui oleh pengguna laporan keuangan maka, image perusahaan akan rusak dan membuat kehilangan kepercayaan pengguna laporan keuangan terutama investor terhadap perusahaan. Perataan laba tidak akan terjadi apabila laba yang dihasilkan perusahaan sesuai dengan harapan perusahaan.

Salah satu contoh perusahaan yang cukup mendapat perhatian pasar yakni pada perusahaan mamin. Perusahaan mamin merupakan perusahaan dengan ukuran besar namun, pada faktanya tidak semua perusahaan besar itu laba yang dihasilkannya benar riil karena, perusahaan dengan ukuran besar cenderung menghindari fluktuasi laba yang drastis yang 
dapat memberikan dampak buruk terhadap perusahaannya sehingga cenderung untuk melakukan perataan laba. Perusahaan ukuran besar ini juga membutuhkan dana yang lebih besar pula, sehingga perusahaan cenderung menginginkan pertumbuhan dalam labanya, dan munculah motivasi terdorongnya melakukan perataan laba. Ditambah lagi dengan penelitian-penelitian terdahulu yang menyatakan bahwa perusahaan manufaktur lebih banyak cenderung melakukan perataan laba dibandingkan dengan perusahaan lainnya. Perusahaan manufaktur yang didalamnya termasuk perusahaan mamin.

Pada penelitian kali ini peneliti tertarik untuk mencoba meneliti kembali berapa banyak perusahaan melakukan perataan laba di perusahaan industri mamin yang terdaftar di bursa efek indonesia. Dengan ini peneliti mengambil judul "Analisis Perataan Laba Referensi Bagi Calon Investor Sebagai Kegunaan Penelitian (Studi Keuangan Perusahaan Industri Makanan dan Minuman)"

\section{TINJAUAN PUSTAKA}

\section{Manajemen Keuangan}

Manajemen keuangan Moh Benny (7:2009) "Namun pada intinya manajemen keuangan merupakan kegiatan dalam menghimpun dan mengelola atau menggunakan uang oleh perusahaan"

Menurut Poppy Alexano manajemen keuangan merupakan manajemen yang mengatur segala hal yang berhubungan dengan masalah keuangan atau pendanaan. Jadi manajemen keuangan sering didefinisikan sebagai cara merencanakan, menganggarkan, memeriksa, mengelola, mengendalikan, mencari, dan menyimpan dana atau uang bagi sebuah lembaga atau perusahaan.

Sedangkan menurut Irham Fahmi (2014) : Manajemen keuangan perusahaan merupakan penggabungan dari ilmu dan seni yang membahas mengkaji dan menganilisis tentang bagaimana seorang manajer keuangan dengan mempergunakan seluruh sumber daya perusahaan untuk mencari dana, mengelola dana, dan membagi dana dengan tujuan mampu memberikan profit atau kemakmuran bagi para pemegang saham dan keberlanjutan usaha bagi perusahaan.

Dari beberapa pendapat para ahli diatas maka dapat disimpulkan bahwa manajemen keuangan adalah segala kegiatan yang berkaitan tentang pendanaan atau keuangan dalam hal merencanakan, mengelola, menyimpan atau menghimpunnya.

\section{Laporan Keuangan}

Laporan keuangan merupakan hal yang sangat penting yang harus dimiliki oleh setiap perusahaan apapun jenis perusahaannya. Berikut ini definisi laporan keuangan beberapa pendapat para ahli :

Menurut Irham Fahmi (2012) "Laporan keuangan merupakan suatu informasi yang menggambarkan kondisi keuangan suatu perusahaan, dan lebih jauh informasi tersebut dapat dijadikan sebagai gambaran kinerja keuangan perusahaan tersebut"

Menurut Munawir (2007) "Laporan Keuangan merupakan alat yang sangat penting untuk memperoleh informasi sehubungan dengan posisi keuangan dan hasil-hasil yang telah dicapai oleh perusahaan yang bersangkutan"

Menurut Myer (dalam Munawir, 2007) yang dimaksud dengan laporan keuangan : Dua daftar yang disusun oleh Akuntan pada akhir periode untuk suatu perusahaan. Kedua daftar itu adalah daftar neraca atau daftar posisi keuangan dan daftar pendapatan atau daftar rugi-laba. Pada waktu akhir-akhir ini sudah menjadi kebiasaan bagi perseroanperseroan untuk menambahkan daftar ketiga yaitu daftar surplus atau daftar laba yang tidak dibagikan (Laba yang ditahan)

Dari beberapa pendapat para ahli diatas maka dapat disimpulkan bahwa pengertian dari laporan keuangan adalah suatu alat terpenting perusahaan yang berisikan sebuah informasi yang bermanfaat serta 
dapat menggambarkan kondisi suatu perusahaan.

\section{Tujuan Laporan Keuangan}

Menurut Irham Fahmi (2012) sebuah laporan keuangan pada umumnya terdiri dari: Neraca, Laporan laba rugi, Laporan perubahan modal, Laporan arus kas, Catatan atas laporan keuangan.

Sedangkan menurut Kasmir (2012) dalam praktiknya, secara umum ada lima macam jenis laporan keuangan yang biasa disusun yaitu: Neraca, Laporan laba rugi, Laporan perubahan modal, Laporan arus kas, Laporan catatan atas laporan keuangan.

Pendapat Arief Sugiono, dan Edi Untung (2016), laporan keuangan terdiri dari 4 laporan dasar, yaitu: Neraca atau Laporan Posisi Keuangan, Laporan Laba Rugi, Laporan Perubahan Modal/Laba Ditahan, Laporan Arus Kas.

Dari beberapa pendapat para ahli diatas maka dapat disimpulkan bahwa jenis jenis laporan keuangan terdiri dari: laporan neraca, laporan laba rugi, laporan perubahan modal, dan laporan arus kas.

\section{Pengaruh Laporan Keuangan Terhadap Investor}

Menurut Irham Fahmi (22:2012) Pengaruh informasi laporan keuangan bagi investor yakni Bagian yang paling dianalisis oleh para investor dalam rangka mengetahui kondisi suatu perusahaan itu sehat atau tidak adalah informasi yang diperoleh dari laporan keuangan yang menggambarkan tentang kondisi keuangan perusahaan seperti diperolehnya informasi tentang tidak likuidnya keuangan perusahaan tersebut, maka ini menunjukkan bahwa perusahaan sudah menunjukan kecenderungan tidak sehat lagi dan membutuhkan dana untuk membantu mencapai likuiditas kembali.

Sedangkan menurut Werner R. Murhadin informasi laporan keuangan berfungsi dalam pengambilan keputusan "Keputusan yang dibuat oleh pihak-pihak ini tidak hanya berupa keputusan untuk membeli, mempertahankan atau menjual suatu saham perusahaan, tetapi juga waktu untuk melakukan tindakan pembelian ataupun penjualan tersebut".

Menurut Dr. Kasmir (2008) pengaruh informasi laporan keuangan bagi investor adalah: Bagi investor yang ingin menanamkan dananya dalam suatu usaha sebelum memutuskan untuk membeli saham, perlu mempertimbangkan banyak hal secara matang. Dasar pertimbangan investor adalah dari laporan keuangan yang di sajikan perusahaan yang akan ditanamnya.

Dari beberapa pendapat para ahli diatas maka dapat disimpulkan bahwa pengaruh informasi laporan keuangan bagi investor adalah hal pengambilan keputusan untuk pembelian saham dengan menilai suatu kondisi perusahaan yang tergambarkan di laporan keuangan.

\section{Teori Keagenan}

Beberapa para ahli menjelaskan pengertian teori keagenan, berikut penjelasannya:

R.A Supriyono mengatakan bahwa "Teori Agensi (Keagenan) adalah konsep yang mendeskripsikan hubungan antara prinsipal (pemberi kontrak) dan agen (penerima kontrak), prinsipal mengontrak agen untuk bekerja demi kepentingan atau tujuan prinsipal sehingga pinsipal memberikan wewenang pembuatan keputusan kepada agen untuk mencapai tujuan tersebut".

Selanjutnya John A. Pearce mengatakan bahwa "Ketika terdapat pemisahan antara pemilik (Principal) dengan manager (Agen) di suatu perusahaan, maka terdapat kemungkinan bahwa keinginan pemilik diabaikan. Fakta ini, dan kesadaran bahwa agen itu mahal, menetapkan landasan bagi sekelompok gagasan rumit namun bermanfaat yang dikenal sebagai teori keagenan (agency theory)."

Dilain pihak menurut Anthony \& Govindarajan (dalam Shaumi:2017) 
mengemukakan asumsi agency theory bahwa "Masing-masing individu sematamata termotivasi oleh kepentingan dirinya sendiri sehingga menimbulkan konflik kepentingan antara principal dan agent".

Dari beberapa pengertian teori keagenan yang dijelaskan oleh para ahli tersebut, maka dapat disimpulkan bahwa teori keagenan adalah adanya suatu hubungan atau kontrak antara principal dan agen dalam mencapai suatu tujuan, namun pihak agen cenderung lebih mementingkan kepentingannya dan mengabaikan keinginan pemilik sehingga muncullah konflik kepentingan yang timbul akibat asimetri informasi. Teori keagenan merupakan cikal bakal terjadinya disfunctional behavior yakni perilaku yang tak semestinya dilakukan oleh manajemen perusahaan dengan melakukan perataan laba. Dalam hal ini setiap pihak memiliki kepentingan yang berbeda. Agen yakni manajemen memiliki kepentingan untuk mencapai tingkat kemakmurannya dengan cara mendapatkan tingkat bonus tunai yang diharapkannya, sementara Prinsipal memiliki kepentingan untuk mencapai tingkat kemakmurannya dengan cara mendapatkan tingkat return yang diharapkan.

\section{Laporan Laba Rugi}

Menurut Irham Fahmi (2012) Laporan Laba Rugi merupakan salah satu dari banyak bagian suatu paket laporan keuangan dan seperti bagian lainnya, laporan laba rugi merupakan bagian dari produk berbagai pilihan, dilaporkan, seperti halnya kebijakan bisnis, kondisi ekonomi, dan banyak variable yang memengaruhi hasil yang dilaporkan

Menurut Werner R. Murhadi(2013) "Laporan Laba Rugi adalah laporan yang menggambarkan kinerja hasil operasional perusahaan selama periode tertentu"

Menurut Sunyoto (2013), pengertian dari laporan laba rugi adalah ; Laporan laba rugi disusun dengan maksud untuk menggambarkan hasil operasi perusahaan dalam suatu periode waktu tertentu. Dengan kata lain laporan laba rugi menggambarkan keberhasilan atau kegagalan operasi perusahaan dalam upaya mencapai tujuannya. Hasil operasi perusahaan diukur dengan membandingkan antara pendapatan perusahaan dengan biaya yang dikeluarkan untuk memperoleh pendapatan tersebut.

Dari beberapa pendapat para ahli diatas maka dapat disimpulkan bahwa laporan laba rugi adalah salah satu bagian dari laporan keuangan yang dilaporkan dalam suatu periode waktu tertentu yang menggambarkan operasi perusahaan dalam keadaan berhasil atau gagal.

\section{Laba}

Pengertian Laba menurut Irham Fahmi (2012) "Laba setelah pajak (earnings after tax) merupakan laba yang diperoleh setelah dikurangkan dengan pajak".

Sedangkan menurut Werner R. Murhadi (2012) "Laba Neto merupakan bagian akhir dalam laporan laba rugi yang mencerminkan kinerja perusahaan dalam memberikan hasil bagi pemegang saham"

Dan menurut Dr. Lyndon Saputra(284) "Laba dapat didefinisikan sebagai peningkatan dalam kesejahteraan. Dalam hal suatu perusahaan, ini dapat dioperasionalkan sebagai arus kas satuan usaha ditambah perubahan dalam nilai perusahaan tersebut"

Dari beberapa pendapat para ahli diatas maka dapat disimpulkan bahwa pengertian laba adalah bagian akhir dalam laporan laba rugi yakni laba setelah pajak yang menggambarkan meningkatnya kesejahteraan suatu perusahaan.

\section{Manajamen Laba}

Manajemen Laba menurut Ahmed Riahi, Belkaoui (2011) "Suatu kemampuan untuk 'memanipulasi' pilihan-pilihan yang tersedia dan mengambil pilihan yang tepat untuk dapat mencapai tingkat laba yang diharapkan"

Sedangkan menurut Herry, S.E (2017) "Manajemen laba dapat memberikan gambaran tentang perilaku manajer dalam 
melaporkan kegiatan usaha pada suatu periode tertentu, yaitu adanya kemungkinan motivasi tertentu yang mendorong mereka untuk merekayasa data keuangan".

Dan menurut Sri Sulistyanto (2008): Secara umum manajemen laba didefinisikan sebagai upaya manajer perusahaan untuk mengintervensi atau mempengaruhi informasi-informasi dalam laporan keuangan dengan tujuan untuk mengelabui stakeholder yang ingin mengetahui kinerja dan kondisi perusahaan.

Dari beberapa pendapat para ahli diatas maka dapat disimpulkan bahwa manajemen laba adalah perilaku manajer terhadap pelaporan keuangan yang didalamnya terdapat beberapa pilihan yang tersedia untuk dimanipulasikan lalu diambil pilihan yang paling tepat untuk mencapai hasil laba yang di harapkan

Scott dalam Mila dan Supatmi (2012) mengemukakan bentuk-bentuk manajemen laba yang dilakukan oleh manajer antara lain:

Taking a bath, dilakukan ketika keadaan buruk yang tidak menguntungkan tidak bisa dihindari pada periode berjalan, dengan cara mengakui biaya pada periode-periode yang akan datang dan kerugian periode berjalan.

Income Minization, dilakukan saat perusahaan memperoleh profitabilitas yang tinggi dengan tujuan agar tidak mendapat perhatian secara politis. Kebijakan yang diambil bisa berupa pembebanan pengeluaran iklan, riset dan pengembangan yang cepat dan sebagainya. Cara ini mirip dengan taking a bath namun kurang ekstrim.

Income

Maximization,yaitu memaksimalkan laba agar memperoleh bonus yang lebih besar. Demikian pula bagi perusahaan yang mendekati suatu pelanggaran kontrak hutang jangka panjang, manajer perusahaan tersebut cenderung untuk memaksimalkan laba.

Income Smoothing (Perataan Laba),merupakan bentuk manajemen laba yang paling sering dilakukan dan paling populer, lewat income smoothing, manajer menaikkan atau menurunkan laba untuk mengurangi fluktuasi laba yang dilaporkan sehingga perusahaan terlihat stabil atau tidak beresiko tinggi.

\section{Perataan Laba}

Menurut Ahmed Riahi, Belkaoui (2011)"Perataan laba adalah pengurangan fluktuasi laba dari tahun ke tahun dengan memindahkan pendapatan dari tahun-tahun yang tinggi pendapatannya ke periodeperiode yang kurang menguntungkan "

Perataan laba menurut Beidlement (1973) (dalam Herry: 2017) bahwa "Sebagai suatu pengurangan dengan sengaja atas fluktuasi laba yang dilaporkan agar berada pada tingkat yang dianggap normal bagi perusahaan"

Sedangkan menurut Sofyan Syafri (2001) menyatakan bahwaa "Praktik perataan laba adalah upaya menstabilkan laba dimana tidak banyak variance dari satu periode ke periode lain sehingga dinilai prestasi baik".

Dari beberapa pendapat para ahli diatas perataan laba ialah tindakan merekayasa laporan keuangan untuk mengurangi variasi laba dengan memindahkan pendapatan dari suatu periode yang tinggi pendapatannya ke periode yang rendah pendapatannya.

\section{Jenis Perataan Laba}

Menurut Herry (2017) Perataan Laba diklasifikasikan menjadi: Operating manipulations dan Accounting manipulations. Manipulasi operasi berkaitan dengan usaha untuk merubah keputusan operasional yang mempengaruhi aliran dana dan pendapatan bersih untuk satu periode. Sedangkan manipulasi akuntansi berkaitan dengan penggunaan fleksibilitas dalam metode akuntansi untuk merubah besarnya laba.

Menurut Utomo dan Siregar (2008) perataan laba dibagi menjadi 2 yaitu :Perataan laba yang terjadi secara alamiah (Naturally Income Smoothing) merupakan sebuah proses yang dilakukan oleh pihak manajemen secara langsung tanpa ada rekayasa. Perataan laba yang disengaja 
oleh manajemen (Intentionally Income Smoothing) terjadi karena adanya campur tangan dari pihak manajemen

Menurut Eckel: 1981 (dalam Silviana: 2011), jenis perataan laba dibagi menjadi dua yaitu : Real smoothing adalah perataan laba yang dilakukan melalui transaksi ekonomi dengan melakukan perubahan kebijakan operasi beserta waktunya. Sedangkan artificial smoothing atau yang sering juga disebut accounting smoothing, yaitu praktik perataan laba yang dilakukan secara sengaja dengan perubahan prosedur dan kebijakan akuntansi yang telah diterapkan untuk memindahkan biaya dan atau pendapatan dari suatu periode ke periode yang lain yang dianggap memerlukan tambahan atau pengurangan jumlah laba sehingga dapat terlihat lebih rata dari tahun ke tahun.

\section{Tujuan dan Motivasi Perataan Laba}

Tujuan perataan laba menurut Herry S.E (2017) adalah: Untuk memenuhi harapan pihak eskternal perusahaan, seperti investor dan kreditur. Pihak eksternal ini memiliki kepentingan atas kinerja perusahaan, dimana mereka menginginkan agar perusahaan dapat terus beroperasi dengan hasil yang baik.

Tujuan perataan laba menurut Suwito (2005): Memperbaiki citra perusahaan di mata pihak luar bahwa perusahaan tersebut tidak memiliki risiko, Memberikan informasi yang relevan dalam melakukan prediksi terhadap laba di masa mendatang, Meningkatkan kepuasan relasi bisnis, Meningkatkan persepsi pihak eksternal terhadap kemampuan manajemen, Meningkatkan kompensasi bagi pihak manajemen.

Tujuan perataan laba menurut Wirawan (2018:67) adalah "Agar omzet yang mereka peroleh stabil, sehingga mereka menarik piutang yang jatuh tempo bulan depan ke bulan ini atau sebaliknya".

Dari beberapa pendapat para ahli diatas perataan laba ini dilakukan bertujuan agar citra perusahaan nampak baik di mata pihak investor yang seolah olah perusahaan tidak memiliki risiko, dan sekaligus juga mampu memenuhi harapan pihak investor selaku pemilik saham. Adapun motivasi dilakukannya perataan laba adalah : Mengurangi total pajak terutang, Meningkatkan hubungan anatara manajer dan karyawan, dan Mengubah persepsi investor terhadap nilai perusahaan.

\section{Unsur dan Tehnik Dilakukannya Perataan laba}

Ada beberapa unsur dalam laporan keuangan yang dijadikan sasaran untuk melakukan perataan laba : yang pertama ialah Unsur Penjualan yakni pada saat pembuatan faktur penjualan, pembuatan pesanan atau penjualan fiktif, dan drowngading (menurunkan nilai produk). Yang kedua ialah unsur biaya yakni mencegah faktur pembelian, memecah faktur pembelian, mencatat biaya dibayar dimuka.

Menurut Harahap (2005) Income Smoothing biasanya dilakukan dengan berbagai cara, yaitu:

Mengatur waktu kejadian transaksi Manajemen dapat menentukan waktu kejadian transaksi aktual terjadi sehingga pengaruhnya terhadap pelaporan pendapatan akan cenderung mengurangi variasinya dari waktu ke waktu. Seringkali, waktu yang direncanakan dari terjadinya peristiwa (contoh penelitian dan pengembangan) akan menjadi fungsi dari aturan akuntansi yang mengatur pengakuan akuntansi atas peristiwa

Memilih prinsip atau metode alokasi Melalui kejadian dan pengakuan atas suatu peristiwa, manajemen memiliki kendali yang lebih bebas terhadap determinasi atas periode periode yang dipengaruhi oleh kuantitatif dari peristiwa. Manajemen dapat mengatur pengalokasian suatu biaya selama beberapa periode akuntansi untuk mengurangi fluktuasi laba yang dilaporkan.

Perataan melalui pengklasifikasian Manajemen memiliki wewenang dan kebi- 
jakan untuk mengklasifikasikan pos-pos rugi laba dalam kategori yang berbeda. Mengatur penggolongan antara laba operasi normal dan laba yang bukan dari operasi normal.

\section{METODE PENELITIAN}

Dalam penelitian ini objek yang digunakan adalah pengukuran Indeks Perataan Laba untuk mengukur perusahaan industri makanan dan minuman yang melakukan perataan laba periode 2014 - 2016. Metode penelitian yang digunakan peneliti untuk menemukan dan mendapatkan jawaban untuk masalah yang di teliti adalah metode penelitian deskriptif. Bambang S.Soedibjo (2005) mengemukakan bahwa "Metode Deskriptif adalah penelitian untuk mengetahui nilai variabel mandiri baik satu atau lebih variabel tanpa membuat perbandingan atau dihubungkan dengan variabel lainnya".

Sedangkan penelitian dengan pendekatan kuantitatif menurut Wijiantoro (dalam Sugiyono, 2011) mengatakan bahwa "Metode Kuantitatif merupakan metode ilmiah karena memenuhi kaidah-kaidah ilmiah yang konkrit/empiris, obyektif, terukur, rasional, dan sistematis". Metode kuantitatif ini mengolah data berupa angka -angka.

Dari beberapa pengertian para peneliti diatas dapat disimpulkan bahwa metode penelitian deskriptif kuantitatif adalah penelitian yang dilakukan untuk mengetahui nilai variabel dengan pengumpulan data berupa angka tanpa perlu membandingkan satu variabel dengan variabel lainnya dan tanpa perlu menghubungkan dengan variabel lainnya ,dimana variabel tersebut mengolah data dengan angka angka.

Populasi dalam penelitian ini adalah perusahaan mamin yang terdaftar di Bursa Efek Indonesia periode 2014 - 2016. Teknik sampel yang digunakan yaitu dengan menggunakan metode purposive sampling. Dengan jumlah observasi 10 perusahaan ma$\min$.
Tabel 1. Seleksi Sampel

\begin{tabular}{|c|c|}
\hline Kriteria & Jumlah \\
\hline $\begin{array}{l}\text { Perusahaan industri makanan \& } \\
\text { minuman yang terdaftar di Bursa } \\
\text { Efek Indonesia periode } 2014- \\
2016\end{array}$ & 14 \\
\hline $\begin{array}{l}\text { Perusahaan industri makanan } \\
\text { \& minuman yang laporan } \\
\text { keuangannya tidak dapat diakses } \\
\text { oleh peneliti }\end{array}$ & (2) \\
\hline $\begin{array}{l}\text { Perusahaan industri makanan } \\
\text { \& minuman yang laporan } \\
\text { keuangannya dari tahun 2014- } \\
2016 \text { merugi }\end{array}$ & (2) \\
\hline Jumlah Sampel & 10 \\
\hline
\end{tabular}

Sumber: Data diolah, 2018

Data penelitian ini menggunakan data sekunder yakni berupa laporan keuangan tahunan yang telah terdaftar di Bursa Efek Indonesia tahun 2014-2016. Sumber data ini didapatkan dari web www.idx. co.id dan http://web.idx.id. Teknik analisis data penelitian ini adalah teknik analisis statistik deskriptif. Jadi data yang telah dikumpulkan dan akan dijadikan sampel diidentifikasi menggunakan analisis statistik deskriptif untuk memberikan gambaran data secara keseluruhan yang digunakan untuk menjelaskan berapa nilai tertinggi Indeks Perataan Laba, nilai terendah, nilai rata-rata dan dengan standar deviasinya dalam suatu sampel penelitian. Lalu dapat digolongkan dengan nilai status terbesar adalah 1 dan nilai terkecil sebesar 0 . Statistik deskriptif ini dijabarkan hanya untuk memberikan informasi saja dan tidak untuk ditarik kesimpulannya.

Dalam penelitian ini, variabel penelitian adalah perataan laba. Praktik perataan laba diukur dengan menggunakan indeks eckel (Utomo dan Siregar, 2008). Indeks eckel ini dilakukan untuk mengetahui perusahaan yang melakukan perataan laba dengan perusahaan yang tidak melakukan perataan laba. Adapun indeks perataan laba dihitung dengan rumus sebagai berikut: 
Tabel 2. Statistik Deskriptif

\begin{tabular}{cccccc}
\hline & N & Min & Max & Mean & Std. Dev \\
\hline Indeks Perataan Laba & 10 & -.04 & 116.87 & 13.7330 & 36.35250 \\
Status & 10 & & & & \\
Valid N (Listwise) & 10 & & & & \\
\hline
\end{tabular}

Sumber : Data diolah, 2018

Indeks Perataan Laba $=$
$C V \Delta I$
$C V \Delta S$

Keterangan:

$\Delta l$ : $\quad$ Perubahan laba dalam satu periode

$\Delta S: \quad$ Perubahan penjualan dalam satu periode

CV: Koefisien variasi dari variabel yaitu standar deviasi dengan nilai yang diharapkan

$\mathrm{CV} \Delta \mathrm{I}$ : Koefisien variasi untuk perubahan laba

CVAS : Koefisien variasi untuk perubahan penjualan

Dimana:

$\mathrm{CV} \Delta \mathrm{l}$ atau $\mathrm{CV} \Delta \mathrm{S}=\underline{\text { Standard Deviation }}$

Atau

$\mathrm{CV} \Delta \mathrm{I}$ dan $\mathrm{CV} \Delta \mathrm{S}=$

$$
\frac{\sqrt{\sum(\Delta \mathrm{x}-\Delta \mathrm{X})^{2}}}{\mathrm{n}-1}: \Delta \mathrm{X}
$$

\section{Keterangan:}

$\Delta \mathrm{x}$ : Perubahan laba (I) atau Penjualan (S)

$\Delta \mathrm{X}$ : Rata-rata perubahan laba (I) atau Penjualan (S)

$\mathrm{N}$ : Banyaknya tahun yang diamati

Apabila $C V \Delta \mathrm{I} \geq \mathrm{CV} \Delta \mathrm{S}$ atau Indeks Perataan Laba 1 maka perusahaan tidak digolongkan perusahaan yang melakukan tindakan perataan laba, sedangkan CV $\Delta \mathrm{l}<$
$\mathrm{CV} \Delta \mathrm{S}$ atau Indeks Perataan Laba $<1$ maka perusahaan digolongkan perusahaan yang melakukan tindakan perataan laba (Lila: 2013)

\section{HASIL DAN PEMBAHASAN \\ Statistik Deskriptif}

Menurut Ronald E. Walpole (dalam Rachmat, 2015:40) "Statistik deskriptif adalah metode-metode yang berkaitan dengan pengumpulan dan penyajian suatu gugus data sehingga memberikan informasi yang berguna". Adapun hasil dari statistik deskriptif dapat dilihat di tabel 2 . Menunjukkan bahwa nilai tertinggi Indeks Perataan Laba (IPL) sebesar 116,87 , nilai terendah sebesar $-0,04$, nilai rata-rata untuk IPL sebesar 13,7330 dengan standar deviasi 36,35250 . Sedangkan nilai status terbesar adalah 1 dan nilai terkecil sebesar 0 (1: melakukan tindakan perataan laba dan 0 : tidak melakukan tindakan perataan laba) dengan jumlah responden 10 .

\section{Analisis Perataan Laba Perusahaan Industri Makanan dan Minuman}

Berdasarkan perhitungan indeks eckel dapat mengetahui perusahaan industri makanan dan minuman yang terindentifikasi melakukan perataan laba. Variabel perata laba adalah variabel dummy, untuk membedakan perusahaan yang teridentifikasi melakukan perataan laba diberi nilai 1 (satu) dan perusahaan yang tidak teridentifikasi melakukan perataan laba diberi nilai 0 (nol). Berikut hasil penelitian dalam tabel 3: 
Tabel 3. Hasil Penelitian

\begin{tabular}{|c|c|c|c|}
\hline $\begin{array}{l}\text { Kode } \\
\text { Perusahaan }\end{array}$ & $\begin{array}{l}\text { Indeks } \\
\text { Perataan } \\
\text { Laba }\end{array}$ & $\begin{array}{l}\text { Perataan } \\
\text { Laba }\end{array}$ & Dummy \\
\hline CEKA & 0.18 & melakukan & 1 \\
\hline DLTA & 1.91 & $\begin{array}{c}\text { tidak } \\
\text { melakukan }\end{array}$ & 0 \\
\hline ICBP & 1.50 & melakukan & 1 \\
\hline INDF & 116.87 & $\begin{array}{c}\text { tidak } \\
\text { melakukan }\end{array}$ & 0 \\
\hline MLBI & 1.34 & $\begin{array}{c}\text { tidak } \\
\text { melakukan }\end{array}$ & 0 \\
\hline MYOR & 1.04 & melakukan & 1 \\
\hline ROTI & 9.62 & $\begin{array}{c}\text { tidak } \\
\text { melakukan }\end{array}$ & 0 \\
\hline SKBM & -0.04 & melakukan & 1 \\
\hline SKLT & 4.39 & melakukan & 1 \\
\hline ULTJ & 0.52 & melakukan & 1 \\
\hline
\end{tabular}

Berdasarkan tabel 3 menunjukkan bahwa secara keseluruhan sampel perusahaan industri makanan dan minuman, $40 \%$ tidak melakukan perataan laba dan $60 \%$ melakukan perataan laba. Perusahaan yang melakukan perataan laba yakni, CEKA, ICBP, MYOR, SKBM, SKLT, dan ULTJ.

\section{SIMPULAN DAN SARAN}

Berdasarkan penelitian tersebut, maka ditarik kesimpulan bahwa dari 10 sampel perusahaan industri mamin terdapat 6 perusahaan yang melakukan tindakan perataan laba, dan 4 perusahaan yang tidak melakukan tindakan perataan laba. Dari analisis sampel perusahaan bahwa nilai tertinggi indeks perataan laba adalah pada perusahaan Indofood Sukses Makmur Tbk dengan nilai IPL sebesar 116,87. Angka tersebut menunjukkan semakin besar maka perusahaan tersebut tidak melakukan perataan laba. Sebaliknya angka IPL yang semakin kecil maka perusahaan tersebut melakukan perataan laba. Nilai terendah indeks perataan laba ada pada perusahaan
Sekar Bumi Tbk. dengan nilai IPL sebesar -0.04 .

Berdasarkan hasil dari penelitian, bisa dijadikan sebagai referensi dan pertimbangan bagi para investor dalam menilai suatu perusahaan, agar untuk berhati hati dalam menempatkan investasinya. Apakah perusahaan tersebut benar benar memiliki laba yang stabil atau bahkan ada penyimpangan, karena nantinya akan berdampak pada hasil keuntungan yang didapat oleh investor.

Keterbatasan penilitian ini adalah hanya menganilisis variabel perataan laba saja, tanpa menghubungkan dengan variabel lain atau dihubungkan dengan faktor faktor yang mempengaruhi variabel perataan laba. Saran dari penilitian ini adalah diharapkan agar penelitian selanjutnya dapat menganilisis variabel perataan laba dengan faktor faktor yang mempengaruhinya. Agar mendapatkan hasil yang lebih akurat penyebab faktor mana saja yang menjadikan perusahaan hingga melakukan perataan laba. 


\section{REFERENSI}

Belkaoui, A. R. (2011). Teori Akuntansi. Jakarta: Salemba Empat. Fahmi, I. (2012). Analisis Laporan Keuangan. Bandung: Alfabeta.

Fahmi, I. (2012). Manajemen Investasi. Jakarta: Salemba Empat.

Harahap, S. S. (2001). Analisa Kritis Atas Laporan Keuangan. Depok: Raja Grafindo Persada. Harahap, S. S. (2011). Teori Akuntansi. Jakarta: Rajawali.

Herry. (2012). Analisis Laporan Keuangan. Jakarta: Bumi Aksara.

Herry. (2015). Analisis Laporan Keuangan. Yogyakarta: CAPS (Center for Akademik Publishing Services).

Herry. (2017). Teori Akuntansi. Jakarta: PT. Grasindo.

Herry, S. (2015). Analisis Kinerja Manajemen. jakarta: grasindo.

Indonesia, B. E. (n.d.). Retrieved januari 2019, from Laporan Keuangan dan Tahunan: http:// web.idx.id

Indonesia, B. E. (2018). Retrieved November 26, 2018, from Laporan Keuangan Dan Tahunan. : www.idx.co.id

Jhon A Pearce II, R. B. (2007). Manajemen Strategis. Jakarta: Salemba Empat.

Kasmir, D. (2012). Analisis Laporan Keuangan. Jakarta: PT Raja Grafindo Persada.

Lila Septia Adi Kusuma, P. N. (2013). Analisis Perataan Laba pada Perusahaan Non Manufaktur. Jurnal Manajemen.

Murhadi, W. R. (2013). Analisis Laporan Keuangan Proyeksi dan Valuasi Saham. jakarta: salemba empat.

Silviana. (2011). Analisis Perataan Laba (Income Smoothing): Faktor-Faktor yang mempengaruhi Perataan Laba pada Perusahaan Manufaktur Sektor Industri Dasar dan Kimia yang Terdaftar di Bursa Efek Indonesia. Fakultas Ekonomi Universitas Gunadarma.

Sugiyono. (2013). Metode Penelitian Bisnis. Bandung: Alfabeta.

Sulistyanto, H. S. (2008). Manajemen Laba. Jakarta: Grasindo.

Suwito, A. H. (2005). Analisis Pengaruh Karakteristik Perusahaan Terhadap Tindakan Perataan Laba Yang Dilakukan Oleh Perusahaan Yang Terdaftar Di Bursa Efek Jakarta . Simposium Nasional AKuntansi VIII, 136-146.

Untung, A. S. (2016). Analisa Laporan Keuangan. Jakarta: Grasiondo

Utomo, S. d. (2008). Pengaruh Ukuran Perusahaan, Profitabilitas, dan Kontrol Kepemilikan Terhadap Perataan Laba pada Perusahaan Manufaktur yang terdapat di Bursa Efek Indonesia . Jurnal Akuntansi Manajemen, 113-114. 